\title{
Jane Austen and Imperialism---A Rereading of Pride and Prejudice
}

\author{
Runjiang Xu \& Yucheng Li \\ English Department, Zhenjiang Watercraft College of PLA \\ No. 130 Taohuawu Road, Zhenjiang 212003, China \\ E-mail: xurunjiang_88@hotmail.com
}

\begin{abstract}
This thesis attempts to search for the clues related to British domestic exploitation of the peasant labors and overseas colonization of other countries after rereading the novel Pride and Prejudice, with an aim to bring out Austen's intimacy with Imperialism. It will offer some insights into a better understanding of provincial world created by Jane Austen.
\end{abstract}

Keywords: Overseas expansion, Imperialism, Jane Austen

\section{Introduction}

Jane Austen's Pride and Prejudice has been long praised as a novel dealing exclusively with love affairs within the provincial world Austen has created. In the past, critics of different schools have studied the novel from various perspectives. Some highly praise the skillful structure of the novel. Some note that the characterization is in the highest degree memorable, while the irony has a radiant shrewdness unmatched elsewhere. There are still some others who write that Austen is a writer with feminist consciousness.

Among different discussions of the novel, few people start their exploration into the novel from Austen's attitudes toward the imperial expansion of her time. Though many scholars have discussed Austen's Mansfield Park about her conspiracy with Imperialism, there exists a critical reservation about Pride and Prejudice to that effect. In view of the critical inadequacy in the appreciation of Pride and Prejudice, this thesis attempts to make a thorough exploration into the imperial concern Austen might have concealed for in the novel.

\section{Domestic Exploitation of the Countryside}

\subsection{The Enclosure Movement}

At the beginning of the novel, Mrs. Bennet asks Mr. Bennet to call on their new neighbor — Mr. Bingley who has bought Netherfield Park and would live there for a long time(Austen, 2003: 1-3). This plot has been for long taken simply as an occasion or a leading cause for the meeting of the four protagonists in the novel.

However, there is another piece of information neglected by past critics either deliberately or unconsciously. The period when Jane Austen had been actively engaged in writing had seen the rapid development of the Industrial Revolution. So far Britain had become the "workshop of the world" and was busily engaged in the colonization of other countries. The Industrial Revolution that had greatly facilitated the development of capitalist economy was initiated and accelerated by the innovation of new machines that in turn had led to mechanization and mass-production. To satisfy the increasing demand of labor force, the rising bourgeoisie class hastened the process of Enclosure Movement and expelled farmers from their farmland. Therefore, the turn of the 18th -19th century had seen the continuity of the Enclosure Movement in which many bourgeoisie representatives went about the countryside doing their business.

\subsection{Mr. Darcy and Bingley, Two Bourgeoisie Representatives}

In Pride and Prejudice, Mr. Darcy and Bingley are just two bourgeoisie representatives who have gone to the countryside to make their fortune. At the very beginning of the novel, they are mentioned by Mrs. Long and some other members of the neighborhood as two gentlemen of property. They are said to have bought a house in the Netherfield and are certainly for girls who wanted to find a good husband (Austen, 2003: 1-3). Though their motivations are not clearly expressed in the novel, their buying of the house could be understood as part of the Enclosure Movement to accumulate capitals and recruit labors largely needed in the industrialization in cities. Therefore, the purchase of house constitutes part of the exploitation of the peasant labors from the countryside of Britain in which Imperialism has been widely accepted and promoted.

By deliberately concealing from the reader Darcy's motivation in moving to the countryside, Austen undoubtedly plays a role in advocating Imperialism. She supports the Empire's culture and hates it to be changed by powers outside. Within her characters' conversations, behaviors and thoughts, she always reveals her adoration of the culture, language and tradition of the Empire called "domestic interiors". Then about a decade later, Mary Evans, in her Jane Austen: Women, Politics and the Novel, argues that "Austen's representation of the domestic includes self-conscious appraisal of 
current politics; her domestic interiors are not tranquil enclaves but spaces resonant with political meaning". Austen's description of domesticity demonstrates her discreet usurpation of the early 19th century domestic ideology, which had been called the "wider foreign empire" (Said, 1993: 90). It means that Imperialism has infiltrated into domesticity. Austen's domesticity may blur readers' eyes about the development of female characters, but a careful thinking may reveal the subtle relationship between Austen and Imperialism.

\section{Overseas Colonization}

\subsection{British Overseas Colonization}

With the large-scale Enclosure Movement at the end of the 18th century, the old organic rural communities were dissolved and new ones forged under the impulse of industrialization. Meanwhile there occurred a new process of relocating England within a much larger circle of the world map. Living in an era when Britain was busily engaged in its wildest domestic exploitation of the poor and overseas colonization of other countries about the world, Austen is certain to be familiar with the idea of imperial expansion. As is pointed out earlier, she shows in Pride and Prejudice a covert interest in domestic exploitation of peasant labors by creating two middle class men who are involved in the Enclosure Movement in the countryside. The same will be true of her interest in overseas expansion carried out by the British Empire. However, past studies about Jane Austen's involvement in Imperialism is confined to her novel Mansfield Park, in which Austen has expressed an unmistakable enthusiasm about overseas exploitation and colonization of other countries. For in the novel, Mansfield Park is supported by overseas plantations. To hold and rule Mansfield is to hold and rule an imperial estate.

\subsection{The Relationship between Netherfield Park and Imperial Expansion Overseas}

Yet much has been reserved about the discussion of Imperialism and colonialism in relation to Pride and Prejudice. Such a critical negligence has been deliberately wrought by critics on the pretext that there is no mention of or even reference to the social or historical events related to British territorial expansion in other countries. Instead, Pride and Prejudice, just like Mansfield Park, is also a novel about how Britain is busily involved in overseas colonization and its impact on domestic life.

If one is familiar with the novel Mansfield Park, he will immediately recognize the similarity between Mansfield Park and Netherfield Park while reading the novel Pride and Prejudice. Apart from offering the four protagonists a place to meet, it also reveals subtly the relationship between the maintenance of the park and the economical profits from overseas colonization and domestic exploitation. It is mentioned in the novel that Mr. Bingley's father became rich through commercial business and has left Bingley an enormous heritage(Austen, 2003: 10). Different from farm business, the commercial business that Bingley's father was engaged in around the turn of the 18th to 19th century would most possibly be business of exploiting the peasant labors moving from countryside to cities or business of preying on the natives in British colonies scattered around the world. Therefore, the money used to support and maintain the park of Netherfield, like that of Mansfield Park, relies on the money gained from domestic exploitation or economic expansion overseas. It is in this sense that the influence of imperial expansion both at home and abroad is at work in Pride and Prejudice, though in a masked way.

\subsection{Military Involvement in Overseas Expansion}

What brings Pride and Prejudice closer to the imperial invasion and domination of other countries is its interest explicitly expressed in military troops moving around the country. If one is careful enough, he is sure to notice that Wickham is such a man that his business is intertwined with the Empire's insatiable snatches for treasure overseas.

In Pride and Prejudice, Wickham is first seen to seduce Darcy's younger sister and try to get more money after he has dissipated his share of money bequeathed to him by Darcy's farther. Then he is seen to deceive Elizabeth that Darcy has been a sly man. Later on, he allures Elizabeth's younger sister to elope with him. Given a second thought, Wickham has been a man whose deeds have much in common with those done by the British Empire to its colonies. For in the colonial period, Britain had been seen to extort treasure from its colonies with the pretension that it was bringing civilization to those colonies.

In fact, Wickham has been an accomplice to the Britain Empire. As is pointed out earlier, Wickham is a military officer in British army moving in and out of the country. Take into consideration the social and historical conditions under which Jane Austen was born and brought up, the reasons for advance or retreat of troops about the country would dawn upon the reader. During Austen's short lifetime, Britain had undergone three wars with America in its protection of its colonies in America. On the other hand, Britain had been in war for 13 years in its competition with French for the domination over the European continent. To support those wars, the military troops had played an indispensable part and Britain had to maintain a considerable amount of soldiers. So the soldiers and officers seen to be moving in and out of the Netherfield Park are those very soldiers engaged in the imperial wars fighting against French and America. For in history there were no other wars being fought during the period when Jane Austen lived. It is in this sense that Mr. Wickham's service is closely linked to the defense of the empire's overseas interests and colonial rivalry with French. 
The very account of Mr. Wickham's career seems to reinforce the efforts of imperial dominance whether it is inside or outside the country.

\section{Jane Austen's implication of Imperialism}

\subsection{No Mention of Wars}

Professor Butler argues that Austen herself lived in contentious times. Like Wordsworth and Coleridge, she served her literary apprenticeship in the 1790s, the decade of the Terror and the Napoleonic Wars, an era in England of polemic and hysteria. Political partisanship shaped the novel of her youth, in content, form, and style. (Marilyn Butler, 1975)

In Pride and Prejudice, there were so many balls and dances that soldiers attended. It seems strange enough there is no explicit mention of adventures or dangers of wars fought overseas with America and French. Usually soldiers are pride of being brave in the battlefields and they would like to tell their experiences whether their stories can be real or just made up. The absence of such kind of experiences shows Austen's complicity with the Empire. She is trying to make her reader to forget the crimes done by the British Empire overseas.

If there are few opportunities to talk about wars and fights at balls, the meeting at Mr. Philip's home shall have encouraged the mention of wars (Austen, 2003: 59). It is a meeting arranged especially for welcoming the soldiers. Unfortunately, officers and others are just playing cards and speak nothing about wars abroad. Though there is a concrete talks depicted between Elizabeth and Mr. Wickham, they just take the weather as their topics and then turned to Mr. Darcy. Usually, we know that when two men meet for the first time, it is inevitable for them to talk about the occupation of each other or incidents and events that have happened both inside and outside the country. But here nothing or even a word related to the wars is mentioned. The deliberate omission of wars or the current events in their daily life offers Jane Austen an opportunity not to criticize the crimes done by the Empire.

Then "the military moved to Brighton" (Austen, 2003: 170) which afterwards is shown to be a coastal city. Since Great Britain is a country of island, the expansion of the Empire needs to take advantage of the sea. It is for sure that the regiment will drive there for a preparation of wars. On the other hand, the youngest of Miss Bennet, as well as other young ladies, feels grievous of the departing soldiers. It is reasonable that they would attribute all the woe-like removing to the wars. However, there is still no word describing wars. Through the association of soldiers with flirtatious young girls, Jane Austen tries to make people forget about bloody scenes to be encountered by the soldiers. On the other hand, Austen seems to suggest that war is like a game between young girls and soldiers. In other words, it is a romantic adventure for soldiers.

\subsection{Austen's Complicity with Imperialism}

About the provincial life Austen has depicted in Pride and Prejudice, Lionel Trilling ever wrote in an essay "Manners, Morals and the Novel" that it is "the buzz of implication" that belongs to each time and each culture, and which is very difficult for those of later times and other cultures to perceive (Trilling, 1987: 22). "The buzz of implication" means the part of a culture made up of half-uttered or unutterable expression of imperial value. They are hinted by small actions, sometimes by the arts of dress or decoration, sometimes by tone, gesture, emphasis or rhythm. Then we find from talks and balls an absence about the wars and other social events. In spite of this silence, Austen could not escape from the accomplice with Imperialism. Besides, in another book discussing the relationship between Imperialism and Western literature, Edward Said also argues that Austen's work is "improbable as art not involved with Empire"(Said, 1993: 55). Although he only selects Mansfield Park for such detailed scrutiny, he never acknowledges that Pride and Prejudice is immune from the influence of colonial expansion and Imperialism.

Throughout Pride and Prejudice, Jane Austen tries to cover her interest in the Empire's colonial expansion abroad and the exploitation of workers at home. Such complicity with the Empire is distinctly born out by the silence imposed on people's conversations about current events in their daily life. Skillful Austen may be in concealing her imperial complex, she lets slip anyway a word about the war being fought between Britain and French. In a letter from Elizabeth, Lydia says, "the world is not peace" (Austen, 2003: 287). Lydia writes to Elizabeth mainly because Wickham wants to leave the army and they want Elizabeth and Darcy's help to that effect. Some readers may well believe that Jane Austen is conveying to reader her hatred of war by depicting Wickham's unhappiness in the army. It is nevertheless not the case for in the novel Jane Austen refuses to offer an opportunity for Elizabeth to help Wickham out of the trouble he believes himself to be caught in. What Wickham detest most is his inability to seek further happiness in army where he has to move around the world.

\section{Conclusion}

Quite contrary to the conventional views that Pride and Prejudice only carries a picture of provincial life that Jane Austen knows best, the discussion of domestic exploitation and overseas colonization well shows that Pride and Prejudice is a novel about Jane Austen's complicity with the Empire's commitment to imperial expansion. Just like Mansfield Park, Pride and Prejudice reveals Austen's attitude toward the British Empire, though in a quite different 
way. Edward Said believes that the constant reference to the overseas dominions in Mansfield Park unfailingly informs the reader of Austen's linkage to the imperial business (Said, 1993). While in Pride and Prejudice, Jane Austen strikes for a deliberate aversion of topics about the wars carried out with America and French in competition for colonial dominance, as well as the Enclosure Movement that drove peasants away from their land. It is just such an aversion that reveals how Austen tries to conceal from her reader the crimes done by the British Empire. Therefore, Pride and Prejudice becomes a novel that unconsciously delineates Austen's close relationship to the Empire that was still growing.

The discussion of Austen's complicity with the British Empire will offer some insights into a better understanding of the cultural and political phenomena discussed in Pride and Prejudice. The movement from cities to the countryside of Mr. Darcy and Bingley is never a coincidence in the construction of the novel. It is just one of the commonest things that Jane Austen has seen in her time. The same is true of the shifting of the military troops about the country. Small may Austen's world seems, inexhaustible implications may be arrived at after a systematical examination about every historical and cultural detail mentioned in the novel. Therefore, much is still needed to be done about the novel if the reader wants to get a better understanding about Pride and Prejudice.

\section{References}

Austen, Jane. (2003). Pride and Prejudice. (1st ed.). Shanghai: The World publishing Corporation. pp. 1-3, 10, 59, 170, 287.

Butler, Marilyn. (1975). Jane Austen and the War of Ideas. Toronto: Oxford UP.

Evans Mary. (1987). Jane Austen and the State. Routledge. pp. 11.

Said, Edward. (1993). Culture and Empire. New York: Alfred A. Knopf. pp 55.

Trilling, Lionel. (1987). The Moral Obligation to be Intelligent: Selected Essays. New York: Powell's Books, pp 22. 